\title{
The Impact of Inservice Inspection on the Reliability of Nuclear Piping
}

\author{
H. H. Woo \\ Prepared for: \\ Pacific Northwest Laboratories \\ Richland, Washington 99352 \\ MPO No. B-D5517-A-L
}

December 1983

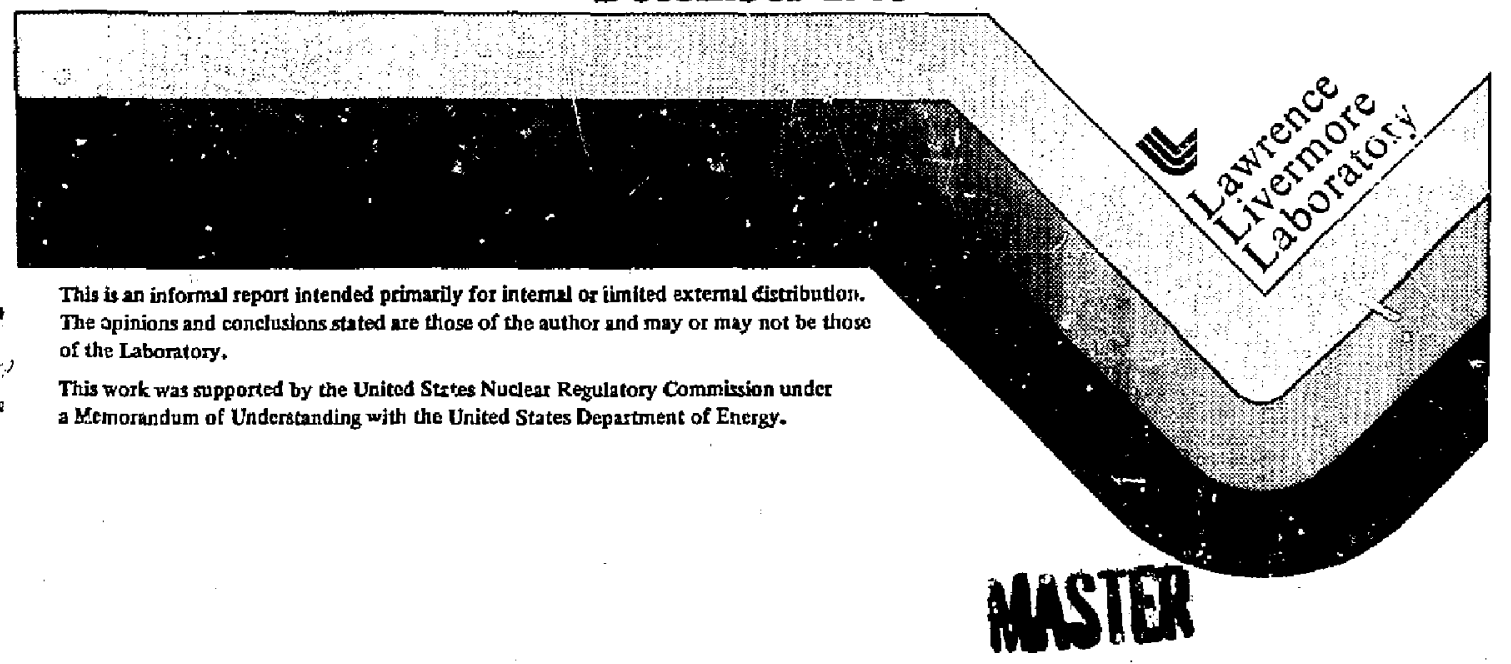

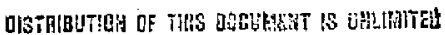


The reliablity of nuclear piping is a function of piping quality as fabricated, service loadings and environments, plus programs of continuing inspection during operation. This report presents the results of a study of the impact of Inservice inspection (ISI) programs on the reliability of specific nuclear piping systems that have actually failed in service. Two major factors are considered in the ISI programs: one is the capability of detecting flaws; the other is the frequency of performing ISI. A probabilistic fracture mechanics model issued to estimate the reliability of two nuclear piping lines over the plant Iife as functions of the ISI programs. Examples chosen for the study are the PWR feedwater steam generator nozzle cracking incident and the EWR recirculation reactor vessel nozzle safe-end cracking incident.

\section{DISCLAIMER}

This report was prepared as an account of work sponsored by an agency of the United States Gavernment. Neither the Uniled Stites Governia ient nor any agency thercof, nor any of their employees, makes any warrsitly. Express or implied, or assumes any legal liability or responsibility for the accuracy, completeness, or usefulness of any information, apparatus, product, or process disclosed, or represents that its use would not infrirge privately owned rights. Reference herein to any specific cominerciai product, process, ar service by trade name. traderaark. manufacturer, or otherwise does not necessarily cosstitute or imply its endarsement, recommendation, or favaring by the United States Government or any agency thereof. The views and opinions of authors expressed herein do nol necessarily state on reflect those of the United States Government of any agency therawt. 
ABS TRACT

ACKNOWLEDOMENTS

viii

EXEOUTIVE SUAMARY

1. IN TRODUCT ION

2. ROUND RGB IN FLAW DETECTION CAPAB ILITY DATA . . . . . . . . . . . 2

2.1 Background. . . . . . . . . . . . . . . . . . 2

2.2 Probatility of Crack Detection . . . . . . . . . . . 2

2.3 Ferritic Steel POD Curves . . . . . . . . . . . 3

2.4 Stainless Steel POD Curves. . . . . . . . . . . . . 4

3. OVERVIEW OF PIPING RElIABILITY MDOEL . . . . . . . . . . 6

4. APPLICATIONS OF PIPING RELIABILITY MODEL TO PWR FEEDWATER LINE CRACK ING IN IDENT . . . . . . . . . . . . . . . . . 9 4.1 Background . . . . . . . . . . . . . . . . . . 9

4.2 Input Data for Piping Rel iablity Model . . . . . . . . . 9

4.3 Results and Discussion . . . . . . . . . . . . . 12

5. APPLICATION OF PIPING RELIABILITY MODEL TO BWR RECIROULATION LINE CRACK ING INCIDENT 5.1 Eackground . . . . . . . . . . . . . . . . . . 22

5.2 Input Data for Piping Keliability Model . . . . . . . 23

5.3 Results and Discussion . . . . . . . . . . . . . . 24

6. OONCLLOING REMARKS . . . . . . . . . . . . . . . 28 REFERENCES. . . . . . . . . . . . . . . . . . 30 
1. Computational procedure used in estimating leak probabilities for nuclear piping.

2. Thermal stratified phengmenon in PuR feedwater lines. . . . . . 10

3a. Cumulative leak probabilities for a PWR (plant A) feedwater steam generator nozzle with respect to three inspection teams and inspection schedules 1,2 and 3 over 40-year plant life. . . . . . . . . 18

3b. Cumulative leak probabilities for a AWR (plant A) feedwater steam generator nozzle with respect to three inspertion teanis and inspection schedules 4, 5 and 6 over 40-year plant life. . . . . . . . . 19

4a. Cumulative leak probabilites for a PWR (plant B) feedrater steam generator nozzle with respect to three inspection teams and inspection schedules 1, 2 and 3 over 40-year plant life. . . . . . . . . 20

4b. Cumulative leak probabilites for a PWR (plant B) feedwater steam generator nozzle with respert to three inspection teams and inspection schedules 4, 5 and 6 over 40-year plant life. . . . . . . . . 21

5. Recirculation-inlet-nozzle safe end configuration at a EWR plant. . 22

6a. Cumulative leak probabilites for a BWR recirculation reactor vessel nozzle safe-end with respect to a poor inspection team and four inspection schedules over 40-year plant life. . . . . . . . . 26

6b. Cumulative leak probabilites for a BWR recirculation reactor vessel nozzle safe-end with respect to a good inspection team and four inspection schedules over 40-yea. plant life. . . . . . . . . 26 
6c. Cumulative leak probabilites for a BNR recirculation reactor vessel nozzle safe-end with respect to an improred inspection team and four inspection schedules over 40-year plant Iife. . . . . . . . . 27 


\section{TABLES}

$\underline{\text { Page }}$

1. Numerical values for ferritic steel POD curves. . . . . . . . 4

2. Numerical values for stainless steel PoD curves. . . . . . . . 5

3. Initial crack depth for PWR feedwater line reliability analysis. . . 10

4. Constants used in fatigue crack growth model for carbon and low-alloy steels. . . . . . . . . . . . . . . . . . . 13

5. Stress results used in fatigue crack growth calculation for design transients. . . . . . . . . . . . . . . . . . 14

6. Stress results used in fatigue crack growth calculation for plant A dur ing thermal stratification conditions. . . . . . . . . . 14

7. Stress results used in fatigue crack growth calculation for plant $B$ during thermal stratification conditions. . . . . . . . . . 15

8. Inspection scenarios for PWR feedwater steam generator nozzle. . . 15

9. Inspecticn scenarios for a BwR recirculation reactor vessel nozzle safe-end. . . . . . . . . . . . . . . . . . 25 


\section{AOKNOWLEDGMENTS}

The author wishes to express his appreciation to F.A. Simanen of Paciffc Nor thwest Laboratory for his support and discussions during the course of the study. Thanks are also extended to $c$. Meler for her editorial effort and to Tracy Dwinell and Nancy Barnes for typing the manuscript. 


\section{EXEOUTIVE SUMAAY}

The necessity for continuing inspection of nuclear power plant components has been recognized for nearly two decades. A joint effort by the U.S. Nuclear Regulatory Comission (ARC) arid the Anerican Siciety of Mechanical Engineers (ASME) during the period of 1966-68 resulted in Section $X I$ of the ASME Boiler and Pressure Vessel Code, "Rules for Inservice Inspection of Nuclear Power Plant compcnents." This code is accepted internationally; however, the adequary of $A S M E$ Section XI for assuring continued operating safety has nat been conclusively established. It is the purpose of this report to study the impact of inservice inspection on the reliability of nuclear piping.

The Pacific Nor thwest Laboratory (PNL) has conducted a piping inspection round $\mathrm{r}$ obin experiment funded by the U.S. MRC to assess the reliability of flaw detection capability on nuclear piping. The PNL Round Robin inspection included three materials and $s i x$ test teams. The inspection effectiveness was evaluated for minimum code requirements, cj-practiceo field procedures, and an improved procedure. Inspections are made under laboratory and simulated field conditions with flaws located on the near and far side of the weld. The team performances are identified as poor, good, and advanced to reflect different flaw detection capabilities relative to the results of the round robin study.

Lawrence Livermore Netional Laboratory (LLNL) has been participating in the piping reliability studies since 1980. A piping reliability model based on the probabilistic fracture mechanics concept was developed by LUNL and has been applied to various piping systems. In the model, inservice inspection was considered a key element in assessing the reliability of piping systems. Inservice inspection consists of two major factors: one is flaw detection capability; the other is inspection schedule. For input on flaw detection capability in this study we have used the PNL round robin results, wile for the inspection schedules we have assumed various inspection scenarios on the basis of Section XI of the ASME code. Two actual failure incidents (ANR feedwater line and BWR recirculation line) were selected to show the impact of inservice inspection on the reliabllity of nuclear piping. Reliability analysis results for the conditions that apply to those two lines led us to conclude the following: 
(1) An effective inservice inspection requires a suitable contination of flaw detection capability and inspection schedule.

(2) The first inservice inspection is the most important one if flaws have the potential to grow to critical size in the early stage of plant operation.

(3) An augmented inspection schedule is required for these particular piping lines wh fast-growth flaws to ensure that the inspection is done before flaws reach critical sizes.

(4) For the PNL round robin study, the improvement in leak probability reduction from the "good" team to the "aovanced" team is less than that from the "poor" team to the "good" team.

In addition, it is concluded that the probabilistic approach presented in the study provides a useful metron to assess the impact of inservice inspection on the reliability of other nuclear piping systems. 


\section{IN TROOUCT ION}

Inservice inspection of light water reactor piping systems has been recognized as one of the ways to improve the reliability and safety of nuclear power plants. Al though the requirements of Section XI of the American Society of Mechanical Engineers (ASME) Boiler and Pressure Vessel Code (hereafter referred to as ASME Code) give guidance on how and where to perform preservice and inservice inspections, the impact of those extensive and expansive inspections on the reliability of thie components being inspected has not been assessed. It is the purpose of this study to assess the impact of flaw detection capability and inspection schedule on the rellability of two selected nuclear piping systems. The information for flaw detection capobility has been gathered from the Iesults of the Piping Inspection Round Rob in Program at the Pacific Northwest Laboratory (PNL). Inspection schedules are primarily selected on the basis of Section XI of the ASME Code. A probabilistic approach is adopted in this study. The model used in the approach was a piping reliablity madel developed for the U.S. Nuclear Regulatory Commission (NRC). 1 The reliability of nuclear piping over plant life is expressed as a function of flaw detection capability and inspection schedule,

The report consists of four sections. Section 2 presents the round robin flaw detection capability data and Section 3 describes the piping reliability model. Sections 4 and 5 describe how the flaw detection capability data are integrated with the piping rellability model and the results of the piping reliability calculations. Section 6 provides the conclusions of the study. 


\section{ROUND ROBIN FLAW OETECTION CAPABILITY DPTA}

\section{$2.1 \quad$ Background}

The piping inspection rourd robin inspection testing ${ }^{2}$ conducted at PNL for the U.S. NRC was aimed at determining the effectiveness of inservice uitrasonic inspection of nuclear syster piping. The round robin included three materials and six test teams. The inspection effectiveness was evaluated for minimum ASME code requirements, as-practiced field procedures, and an improved procedure, Inspections wers made under laboratory and simulated field conditions with flaws located on both the near and far side of the weId. In the following, we will present the results of the probability of crack detect:on (POO) curves for use in the analysis given in section 3 .

\subsection{Probabijity of Crack Detection}

The probability of crack (or flaw) Jetection (POD) is defined as the probab:1ity that a crack with certain specified physical characteristics (e.g., size) is found during an inspection and correctly classified as a crack. POD is directly measured by counting up the number af times cracks of $\therefore$ given category are successfully dicccici, then dividing by the total namber of tines these cracks are subject to inspection.

The rorinal cumulative distribution function, $\Phi^{3}$, was used tc rit the round robin data. The functional iorm is

$$
P O D=\Phi(x)=\int_{-\infty}^{x} \frac{1}{\sqrt{2 \pi}} e^{-t^{2} / 2} d t, \text { and } x=U+B \ln \left(\frac{a}{t}\right)
$$

where $U$ and $\theta$ are constants related to pipe materials, Ultrasonic inspection procedures and inspection access. The dimensions $a$ and $t$ are crack deptin and pipe wall thickness, respectively. The probability of crark non-detection $P_{30}$ is defined as

$$
\mathrm{P}_{\mathrm{ND}}=1-\mathrm{POD} .
$$


Tnree POD curves identified ae "Foor," "good," and "advanced" teams were defined as follows: ${ }^{4}$

1. Poor team: this curve represents a lower bound on performance among round robin teams.

2. Cood team: this curve represents the better teams in the round rchin.

3. Advanced team: this curve represents the performarice that may be achieved with improved procedures ant existing technology. It assumes a 0.9999 flaw ditection probability for a through-wall flaw. A probability of detection o" about 90 percent for a flaw with a depth oi in percent oi the wall was assumed.

In the following sections, we will present the foo curves in the form of Eq. (1) for bodn ferritic steel and stainless steel materials.

\subsection{Ferritic Steel POD Curves}

Three POD curves ${ }^{4}$ ware generated by fitting round robin data for ferritic steel under the conditions where personnel followed the code procedures and had near side access for their inspection.

- Poor team

$$
P O D=\$[0.432+0.163 \ln (a / t)]
$$

- $\operatorname{cood}$ team

$$
P O D=\Phi[1.75+0.583 \ln (a / t)]
$$

- Advanced team

$$
\mathrm{POD}=\$[3.63+1.106 \ln (\mathrm{a} / \mathrm{t})]
$$


These functions apply to flaw depth greater than 5 percent of wall thickness. $A$ detection capability of $P O D=0.0$ for $a / t=0.0$ was assumed, and a linear interpolation with $a / t$ was used between 0 and 5 percent of wall thickness. Some numerical values of ferritic steel POD are presented in Table 1.

Table 1. Numerical values for ferritic steel POD* curves.

\begin{tabular}{|c|c|c|c|}
\hline \multirow[b]{2}{*}{$a / t$} & \multicolumn{3}{|c|}{$\mathrm{POD}$} \\
\hline & Poor & Good & Advanced \\
\hline $\begin{array}{l}0 . \\
.005 \\
.01 \\
.02 \\
.03 \\
.05 \\
.10 \\
.25 \\
1.00\end{array}$ & $\begin{array}{l}0 . \\
0.048 \\
0.096 \\
0.191 \\
0.287 \\
0.478 \\
0.522 \\
0.572 \\
0.666\end{array}$ & $\begin{array}{l}0 . \\
0.045 \\
0.1 \\
0.2 \\
0.3 \\
0.5 \\
0.655 \\
0.826 \\
0.96\end{array}$ & $\begin{array}{l}0 . \\
0.062 \\
0.125 \\
0.25 \\
0.375 \\
0.624 \\
0.86 \\
0.982 \\
0.9999\end{array}$ \\
\hline
\end{tabular}

* POD: probability of crack detection

\section{2. $4 \quad$ Stainless Steel FOD Curves}

Three POD curves ${ }^{5}$ for 10 -inch stainless steel piping with stress corrosion cracks were fitted to the round robin cata. The conditions for performing ultrasonic inspections were that inspectors had near-side access and that they followed field inspection procedures.

- Poor team

$$
P O D=\Phi[0.24+1.485 \ln (a / t)]
$$

- $\quad$ cood team

$$
\begin{gathered}
P O D=\Phi[1.526+0.533 \ln (\mathrm{a} / \mathrm{t})] \\
-4-
\end{gathered}
$$


- Advanced team

$$
P O D=\Phi[3.63+1.106 \ln (a / t)]
$$

Again, these functions apply for flaw depths greater than 5 percent of the wall thickness. A detection capability of $P O O=0.0$ for $a / t=0.0$ was assumed, and a linear interpolation with $a / t$ was used between 0 and 5 percent of wall thickness. Table 2 gives some numerical values for stainless steel POD.

Table 2. Numerical values for stainless steel Poo* curves.

\begin{tabular}{clll}
\hline & & \multicolumn{2}{c}{ POD } \\
\cline { 2 - 4 }$a / t$ & Poor & Good & Advanced \\
\hline 0.005 & 0. & 0.047 & 0.062 \\
.010 & 0. & 0.047 & 0.062 \\
.020 & 0. & 0.094 & 0.25 \\
.030 & 0. & 0.189 & 0.375 \\
.050 & 0.0 .287 & 0.524 \\
.1 & 0.001 & 0.472 & 0.86 \\
.2 & 0.016 & 0.617 & 0.968 \\
.4 & 0.131 & 0.748 & 0.9956 \\
.7 & 0.386 & 0.85 & 0.9994 \\
1.0 & 0.595 & 0.909 & 0.9999 \\
\hline
\end{tabular}

* POD: probability of crack detection 
The piping reliability model was developed on the basis of probab!listic fracture mechanics concepts. The computational procedure (FIg. 1) for the estimation of leak probability momines various random variables, such as initial crack size distribution, flaw (or crack) detection probability, crack growth relation, and the deterministic stress history. The computation starts with the initial size of crack-like defects (i.e., flaws) at a given iucation. These growing cradks are detected with a certain probability during preservice and inservice inspections. Cracks that escape detection and repair can grow following subcritical crack growth characteristics such as fatigue crack growth and stress corrosion cracking. The critical crack size for leak can be defined by using an appropriate criterion (e.g., through-wall cracking). The probability of leak at the pipe location analyzed is equal to the probability of a crack growing to corresponding critical size within the specific time. The Monte Carlo method was used in the numerical simulation. It is obvious that crack detection capability and inspection time are influential on the leak probability results since they are the ist elements to prevent pipe leak once the crack grows in the simllation. The following 1 ists variables required in the computatiors.

1. Fipe material and properties.

2. Fipe geometry: pipe cross section dimensions.

3. Initial crack depth distribution.

4. Loadings and associated occurrence rates: loadings may include pipe internal pressure, dead weight, thermal restraint load, residual stress, vibratory stress, and seismic load. Dccurrence rates for different loadings can be specified.

5. Crack growth models: $d a / c h=f_{1}(c, m, \Delta K$ ) for fatigue crack growth and $d a / d t=f_{2}(c, m, k)$ for stress corrosion cracking where $c$ and $m$ are material constants; $K$ and $\Delta K$ are the applied stress 


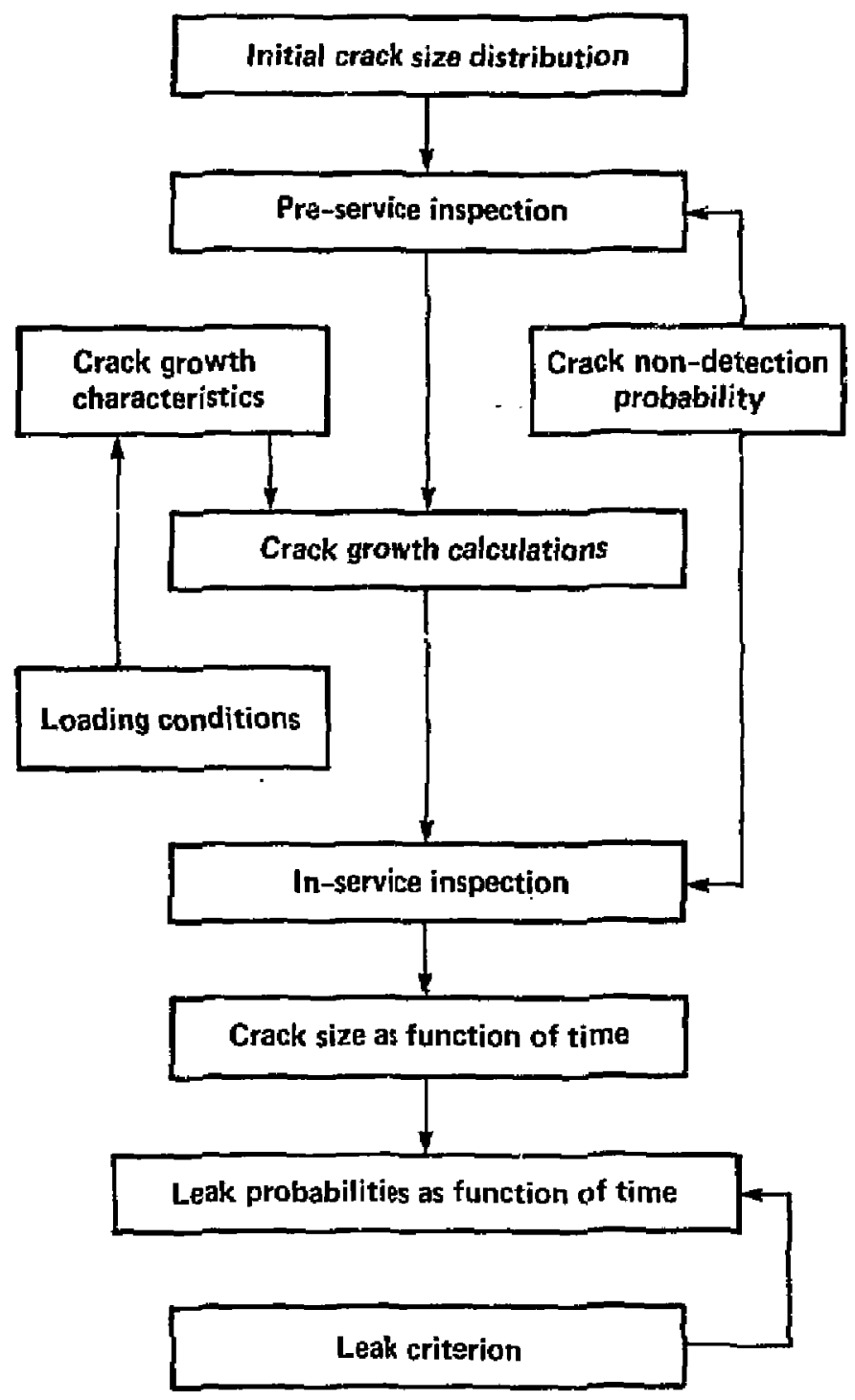

Figure 1. Computational procedure used in estimating leak probability for nuclear piping. 
intensity factor and its range; respectively, $n$ is the number of cycles, and $t$ is the time variable.

6. Detection probability models for cracks and leaks.

7. Inservice inspection schedules.

In the following sections, two actual pipir.g leak incidents were chosen to denonstrate the impact of flaw detection capability on the reliability of nuclear piping by using the piping reliability model just described. The leak incidents are: (1) PWR feeckater line cracking incident, and (2) BWR recirculation line cracking incident. Two plants identified as plant $A$ und plant $B$ were studied for incident (1), and only one plant was studied for incident (2).

The variable for initial crack size distribution at the beginning of the simulation was assigned a fixed or deterministic value. The initial crack depth was determined such that the specific crack size at the specific time would be identical to the one observed during the incident. Mean-value curves for crack growth models were used in determining the injtial crack size. However, in the real simulation, a probabilistic crack growth model was used. Three flaw detection probability curves in conjunction with various inspection schedules were considered. A leak due to through-wall cracking was defined as the failure criterion. The probabilities of leak were then expressed as a function of plant life. 


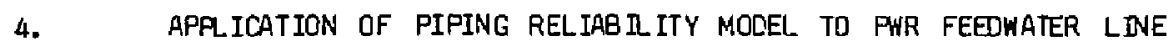
CRACKING DNCIDENT

\subsection{Backoround}

On May 20, 1979 the Indlana and Michigan Power Company informed the MRC of cracking in two feedwater lines at D.C. Cook Unit 2. Circumferential through-wall cracks were detected at the 16-in. lines in the junction of the feecwater lines and steam generator. Subsequent rolumetric examination by radiography revealed crack indications at similar locations in all feedwater lines of both Units 1 and 2. As a result of this incident, the NRC Offices of Inspection and Enforcement issued I.E. Bulletin 79-13 requiring inspection of all PWR feedwater lines. Inspections through March 1980 revealed pipe cracks or fabrication defects requiring repair in the vicinity of the feedwater nozzles at 16 of 35 PWR plants. 6

Extensive studies, including metallergical analysis, in-plant instrumentation, and thermohydraulic modelling, led to the conclusion that the primary cause of cracking was a fatigue mechanism induced by thermal stratification during low-flow auxiliary feedwater injections. ${ }^{7}$ Thermal stratification usually accurs during plant-hot-stanchy, startup, and shutdown conditions. During such conditions, horizontal portions of the feedwater line are subjected to large temperature differences between the top and battom of the pipes. This phenomenon is illustrated in Fig. 2. These stratified teniperature conditions vary rapidly during low-pawer operations and can induce high cyclic thermal stresses in the feedwater nozzle where cracking has occirred.

\subsection{Input Data for Piping Reliablity Model}

1. Pipe geometry and material

Size/schedule: 16/80 (pipe), 16/60 (nozzle)

Material: Al06 GrB (pipe), SA508 Class 2 (nozzle)

2. Initial crack depth

Table 3 gives the calculated initial crack depths for plants $A$ and $\mathrm{B}$. 
Hot

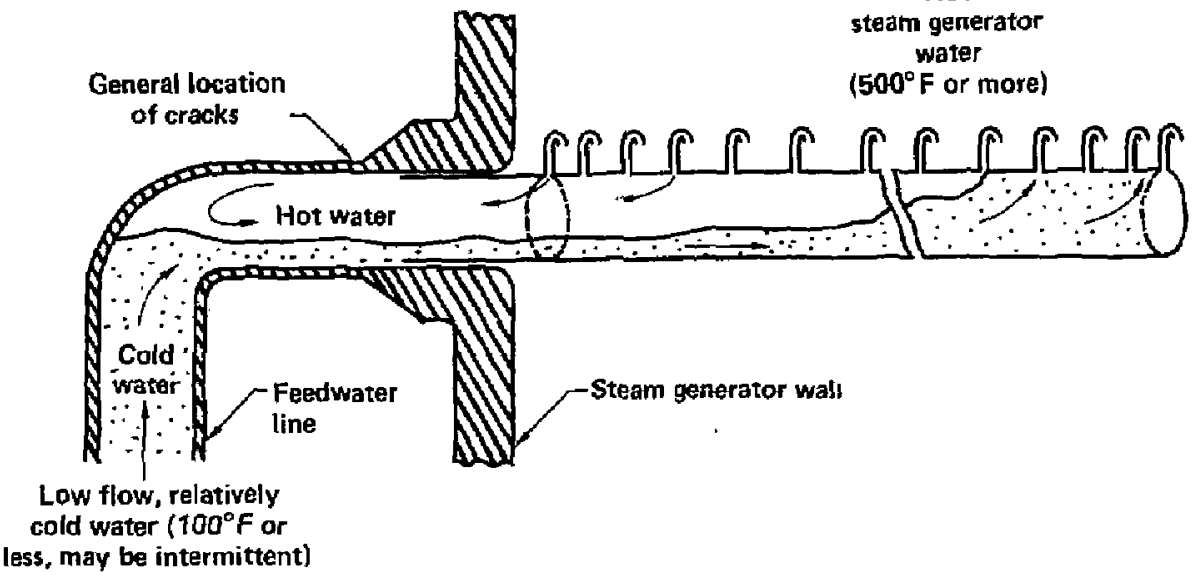

Figure 2. Thermal stratified phenomenon in PWR feedwater lines.

Table 3. Initial crack depth for FUR feedwater line reliability analysis.

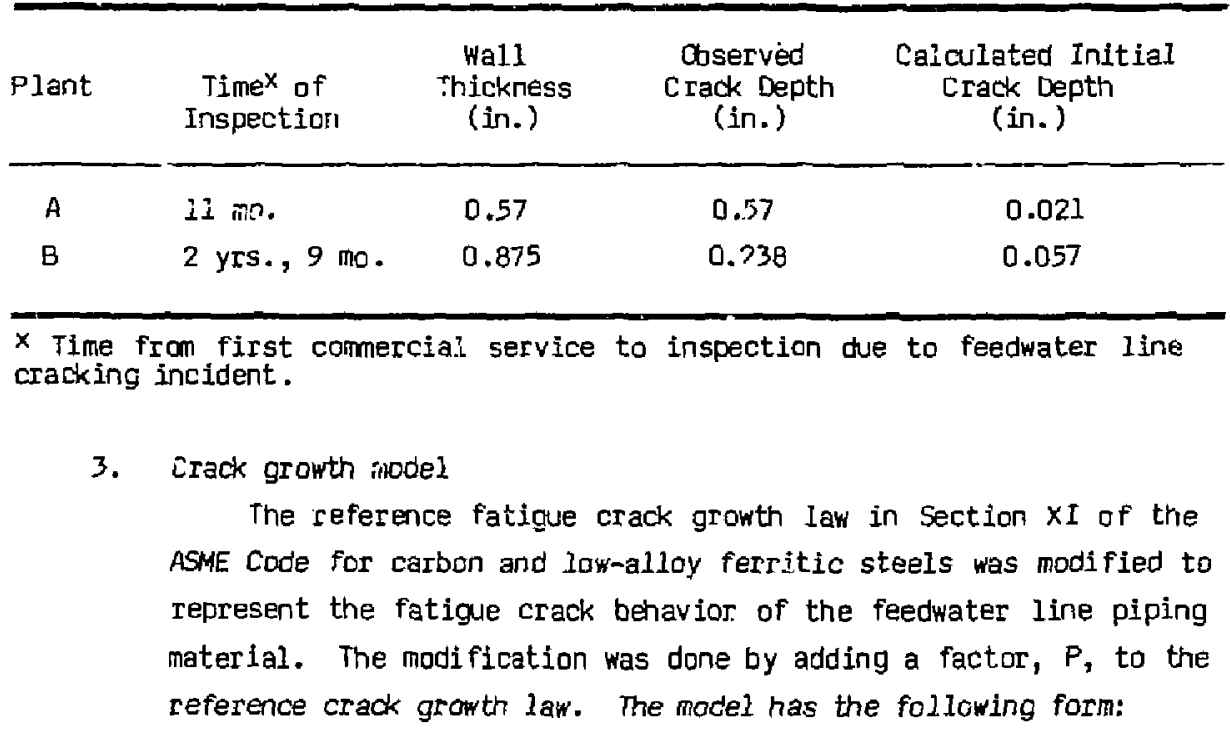




$$
\frac{d a}{d n}=P\left[C(k)^{m}\right]
$$

where $P$ is lognormally distributed ( $\mu$ the mean value, and $\sigma$ the standard deviation). The ranjomess of $P$ reflects the distribution of test data for the material crack growth characteristics. ${ }^{10}$ The value of $\Delta K$ is the difference between the maximum and minimum values of crack tip stress intensity factors $\left(\kappa_{I}\right)$ resulting from the changing stresses during a given stress cycle. For the present analysis, a linearized stress field is assumed for stresses through the pipe wall thickness. The expression below is used to calculate $\mathrm{k}_{\mathrm{I}}$. ll

$$
K_{1}=\sqrt{\pi}\left(A_{a} F_{1}+\frac{2 a}{\pi} A_{1} F_{2}\right)
$$

where

$$
\begin{aligned}
& a=\text { crack depth, } \\
& A_{0}=\text { axial stress at inside surface, } \\
& A_{1}=\frac{\sigma_{0}-A_{0}}{t}, \\
& g_{0}=\text { axial stress at outside surface, } \\
& t=\text { wall thickness } \\
& F_{1}=1.125+0.234 \mathrm{a} / \mathrm{t}+2.20(\mathrm{a} / \mathrm{t})^{2}-0.208(\mathrm{a} / \mathrm{t})^{3} \\
& F_{2}=1.073+0.267 \mathrm{a} / \mathrm{t}+0.666(\mathrm{a} / \mathrm{t})^{2}+0.635(\mathrm{a} / \mathrm{t})^{3} .
\end{aligned}
$$

The stress profile is represented by the linearization,

$$
a=A_{0}+A_{1} \times
$$

Where $x$ is the radial distance measured from the insioe surface of the pipe.

Denoting $R$ as the ratio of $k_{m i n}$ and $k_{m a x}$, we have Table 2 showing various values of $c, m, H$, and a for different ranges of $R$ and $4 k$. 
4. Loading conditions

The transients used as a design basis for the feedwater lines are listed in Table 5, along with the number of expected occurrences in the 40-year-design lifetime of a typical PHR plant. The transient occurrence is divided equally for the entire lifetime. For each transient, the pressure and temperature changes are used to calculate stress. The results are presented in Table 5.12 Results of high cyclic thermal stresses resulting from thermal stratification phenomena for feedwater lines at plants $A$ and $B$ are presented in Tables 6 and 7 , respectively. ${ }^{12}$ In these tables, $\sigma_{m}$ and $a_{b}$ are defined as membrane and bending stresses, respectively. The relationship between $\sigma_{m}, \sigma_{b}, A_{0}$ and $A_{l}$ (see Eq. 6) can be expressed as follows:

$$
\begin{aligned}
& A_{0}=a_{m}+a_{b} \\
& A_{1}=-2 a_{b} / h
\end{aligned} .
$$

5. Crack detection probability

Three crack detection probability curves as represented in Eq. (3) were used for the feedwater line piping materlal. Those curves are referred to as the poor, good, and advanced as described in Section 2.2.

6. Inservice inspection schedules

Table 8 presents six scenarios for inspection schedules. Inspections were assumed to be performed at the end of the year indicated in the table.

\section{$4.3 \quad$ Results and Discussion}

Cumulative leak prabability risults for both plants $A$ and $B$ over 40 -year plant 11 fe are expressed as functions of inspection scenarios and crack detection capabilities. Flgure $3 a$ shows the leak probabilities for plant $A$ ith inspection scenarios 1,2 , and 3 . It can be 5 . : that the leak probability increases very fast from zero to unity within the first five years when no 
Table 4. Constants used in fatigue crack growth model for the carbon and law-alloy steels.

\begin{tabular}{|c|c|c|c|c|}
\hline \multirow{2}{*}{ Ranges for $R$ and $\Delta K$} & \multicolumn{4}{|c|}{ Constants } \\
\hline & C & in & $\mu$ & $\sigma$ \\
\hline \multicolumn{5}{|l|}{$R \leq 0.25$} \\
\hline$\Delta K^{\dagger}<19$ & $1.02 \times 10^{-6}$ & 5.95 & -0.408 & 0.542 \\
\hline$K \geq \geq 19$ & $1.01 \times 10^{-1}$ & 1.95 & -0.408 & 0.542 \\
\hline \multicolumn{5}{|l|}{$R \geq 0.65$} \\
\hline$\overline{4 K}<12$ & $1.2 \times 10^{-5}$ & 5.95 & -0.367 & 0.817 \\
\hline$\Delta K \geq 19$ & $2.52 \times 10^{-1}$ & 1.95 & -0.367 & 0.817 \\
\hline \multicolumn{5}{|l|}{$0.65>\Omega>0.25$} \\
\hline $\mathbb{K}<12+7 W^{*}$ & $1.2 \times 10^{-5} W+1.02 \times 10^{-6} W^{\prime}$ & 5.95 & $-0.367 W-0.408 W^{\circ}$ & $0.817 W+0.542 W^{\prime}$ \\
\hline$\Delta k \geq 12+7 W$ & $2.52 \times 10^{-1}{ }_{W}+1.01 \times 10^{-1} W^{-}$ & 1.95 & $-0.367 W-0.408 W^{\circ}$ & $0.617 W+0.542 W^{\prime}$ \\
\hline
\end{tabular}


Table 5. Stress results used in fatigue crack growth caloulation for design transients.

\begin{tabular}{|c|c|c|c|c|c|}
\hline \multirow{2}{*}{ Design transients } & \multirow{2}{*}{$\begin{array}{l}\text { No, of } \\
\text { cycles in } \\
40 \text { years }\end{array}$} & \multicolumn{2}{|c|}{$\begin{array}{l}\text { Axial stress in ksi } \\
\text { Inside sur fare }\end{array}$} & \multicolumn{2}{|c|}{$\begin{array}{l}\text { Axial stress in ksi } \\
\text { Dutside surface }\end{array}$} \\
\hline & & 䌾ifmum & Minimum & Maximum & Mininum \\
\hline $\begin{array}{l}\text { Hot standby } \\
\text { Unit load-unload } \\
\text { 5\% per minute }\end{array}$ & $\begin{array}{l}18,300 \\
18,300\end{array}$ & $\begin{array}{l}4.77 \\
5.07\end{array}$ & $\begin{array}{l}3.67 \\
3.04\end{array}$ & $\begin{array}{l}4.77 \\
4.01\end{array}$ & $\begin{array}{l}3.67 \\
4.66\end{array}$ \\
\hline Small stepload decrease & 2,000 & 4.53 & 3.33 & 3.83 & 3.83 \\
\hline Large stepload decrease & 200 & 8.04 & 3.83 & 1.40 & 3.83 \\
\hline Loss of power & 40 & 17.27 & 3.66 & -4.9 & 3.66 \\
\hline Partial loss of flow & 30 & 17.41 & 3.37 & -1.34 & 3.66 \\
\hline Loss of load & 80 & 17.7 & 3.76 & -1.04 & 4.76 \\
\hline Reactor trip & 400 & 26.56 & 2.25 & -7.34 & 4.37 \\
\hline Secondary side hydrotest & 5 & 5.68 & 4.37 & 5.68 & 4.37 \\
\hline
\end{tabular}

Table 6 . Stress results used in fatijue crack growth calculation for plant $A$ during thermal stratification conditions.

No. of cycles extimated up to the incident $\frac{\text { Maximum stress in ksi }}{\sigma_{0}} \quad \frac{\text { Minimum stress in ks i }}{\sigma_{m}}$

17.27

17.32

15.82

17.32

16.46

17.32

15.75

15.75

11.55

8.83

8.83

8.83

8.83

8.82

8.37

6.89

\section{$-39.85$}

$-30.53$

$-26.45$

$-21.84$

$-21.40$

$-21.84$

1.65

2.41

2.35

2.41

0 .

5.17

7.79

9.46

9.46

9.46
$-51.88$

$-41.32$

$-38.48$

$-31.37$

$-33.43$

$-31.37$

$-7.8 I$

$-7.81$

$-6.62$

$-6.56$

0.

$-2.28$

3.83

4.44

4. 44

4.44 
Table 7. Stress results used in fatigue rack growth calculation for plant $\mathrm{B}$ during thermal stratification conditions.

\begin{tabular}{|c|c|c|c|c|}
\hline \multirow{2}{*}{$\begin{array}{l}\text { No. of cycles estinated } \\
\text { up to the incident }\end{array}$} & \multicolumn{2}{|c|}{ Maximum stress in ksi } & \multicolumn{2}{|c|}{ Min Imum stress in ks } \\
\hline & $\sigma_{\mathrm{m}}$ & क & $\sigma_{m}$ & b \\
\hline 270 & 27.29 & 15.75 & -35.90 & -47.15 \\
\hline 90 & 24.38 & 12.84 & -36.52 & -46.52 \\
\hline 1170 & 23.75 & 13.46 & -27.20 & -37.20 \\
\hline 90 & 21.93 & 9.46 & -17.98 & -26.74 \\
\hline 540 & 20.07 & 11.31 & -16.04 & -24.74 \\
\hline 180 & 20.77 & 10.61 & -8.89 & -17.65 \\
\hline 360 & 20.31 & 11.08 & 1.79 & -6.97 \\
\hline 2340 & 20.07 & 11.31 & 2.98 & -5.82 \\
\hline 630 & 19.31 & 8.41 & 2.98 & -5.72 \\
\hline 540 & 17.16 & 7.55 & 2.98 & -5.72 \\
\hline 450 & 14.93 & 6.24 & 2.69 & -5.40 \\
\hline 40 & 14.64 & 6.53 & 0. & 0. \\
\hline 50 & 14.64 & 6.53 & 5.46 & -1.84 \\
\hline 670 & 10.60 & 3.31 & 4.32 & -0.7 \\
\hline 2070 & 9.46 & 4.44 & 8.42 & 4.06 \\
\hline
\end{tabular}

Table 8. Inspection scena: ios for PWR feedwater line steam generator nozzle.

\begin{tabular}{|c|c|c|}
\hline Scenario & Description & Inspection time (end of year) \\
\hline 1 & ASME Program A* & $3,10,23,40$ \\
\hline 2 & $\begin{array}{l}\text { 1/2 inspection intervals } \\
\text { of Scenario } 1\end{array}$ & $1.5,3,6.5,10,16.5,23,31.5,40$ \\
\hline 3 & $\begin{array}{l}\text { 1/5 inspection intervals } \\
\text { of Scenario } 1\end{array}$ & $\begin{array}{l}0.6,1.2,1.8,2.4,3,4.4,5.8, \\
7.2,8.6,10,12.6,15.2,17.8, \\
20.4,23.26 .4,29.8,33.2,26.6,40\end{array}$ \\
\hline 4 & ASME Progran $B^{*}$ & $10,20,30,40$ \\
\hline 5 & $\begin{array}{l}1 / 2 \text { inspection intervals } \\
\text { of Scenario } 4\end{array}$ & $5,10,15, \ldots, 40$ \\
\hline 6 & $\begin{array}{l}\text { 1/5 inspection intervals } \\
\text { of Scenario } 4\end{array}$ & $2,4,6, \ldots, 40$ \\
\hline
\end{tabular}

* Refers to ASME Boiler and Pressure Vessel Code, Section XI, Inservice Inspection Programs 
inspection is performed. For different inspection scenarios, as shown in Fig. $3 a$, scenarios 1 and 2 do $r$ ot help significantly in reducing the leak probability (dropping from unity to a value under 0.9), wile scenario 3 cuts the isak probaisility down to a value of 0.5 starting from the fifth year. Fiszthermare, the effect of different inspection teams (poor, good, advanced) begins to have a significant impact on leak probability when an augmented inspection program such as scenario 3 is adopted. Similarly, Fig. 3b shows leak probabilities for plant $A$ with inspection scenarios 4,5 , and 6 . It is clear that only inspection scenario 6 has a slight impact on the leak probability, and scenarios 4 and 5 show no effect at all since the first inspection schedules for both scenarios are beyond the rifth year.

Figures $4 \mathrm{a}$ and $4 \mathrm{~b}$ show the leak probabilities for plant $\mathrm{B}$ over a 40 -year plant life with inspection scenar $\operatorname{los} 1,2$, and 3 and scenarios 4, 5, and 6 , respectively. It is important to point out tha's the leak probabllity with no inspection does nat increase as fast as does the case represented by plant $A$. Furthermore, the leak probability approad,es unity around the 25th year. Because the first inspection schedules for all $5 i x$ scenarios are scheduled long before the 25th year, all scenarios have a positive impact on the leak probabilities. In yeneral, scenario 3 shcws the greatest reduction on leak probability (less than the value of 0.1 ) when compared with the case of no inspection. The res $\mathrm{lts}$ for scenarios 2 and 6 are comparable; their maximum leak probabilities are between 0.2 and 0.4 . Scenarios 1, 4, and 5 also show improvement in reducing the leak probabilities to about $0.6,0.9$, : 0.7 , respectively.

Although we have adopted six inspection scenarios for our rellability assessment on pipe Ieak at PWR feedwater line steam generator nozzles, it is obviaus that some irispection scenaríns are not realistic (e.g., scenario 3), since inservice inspections are usually performed during the period of scheduled outages. The selection of six inspectiun scenarios was intended to cover a wide range of inspection schedules. Interpolation of leak probabilit.es resulting from these six scenarios should give a gooc estimate for other inspection scenarios. The results shown in Figs. 3 and 4 do not indicate large differonces in predicted leak proicililities as a function of flaw detection capability (FOO curves). This is in: part due to the satisfactory performance for 
ferritic piping of even the "poor" team in the ANL piping inspection round robin. Mother important factor is the relatively high leak probabilities for the PWR feedwater lines early in the plant $11 \mathrm{fe}$. In this si.tuation, the inspection interval is of overriding importance. An outstanding detection capability does not offset the impact of an untimely inspection. 


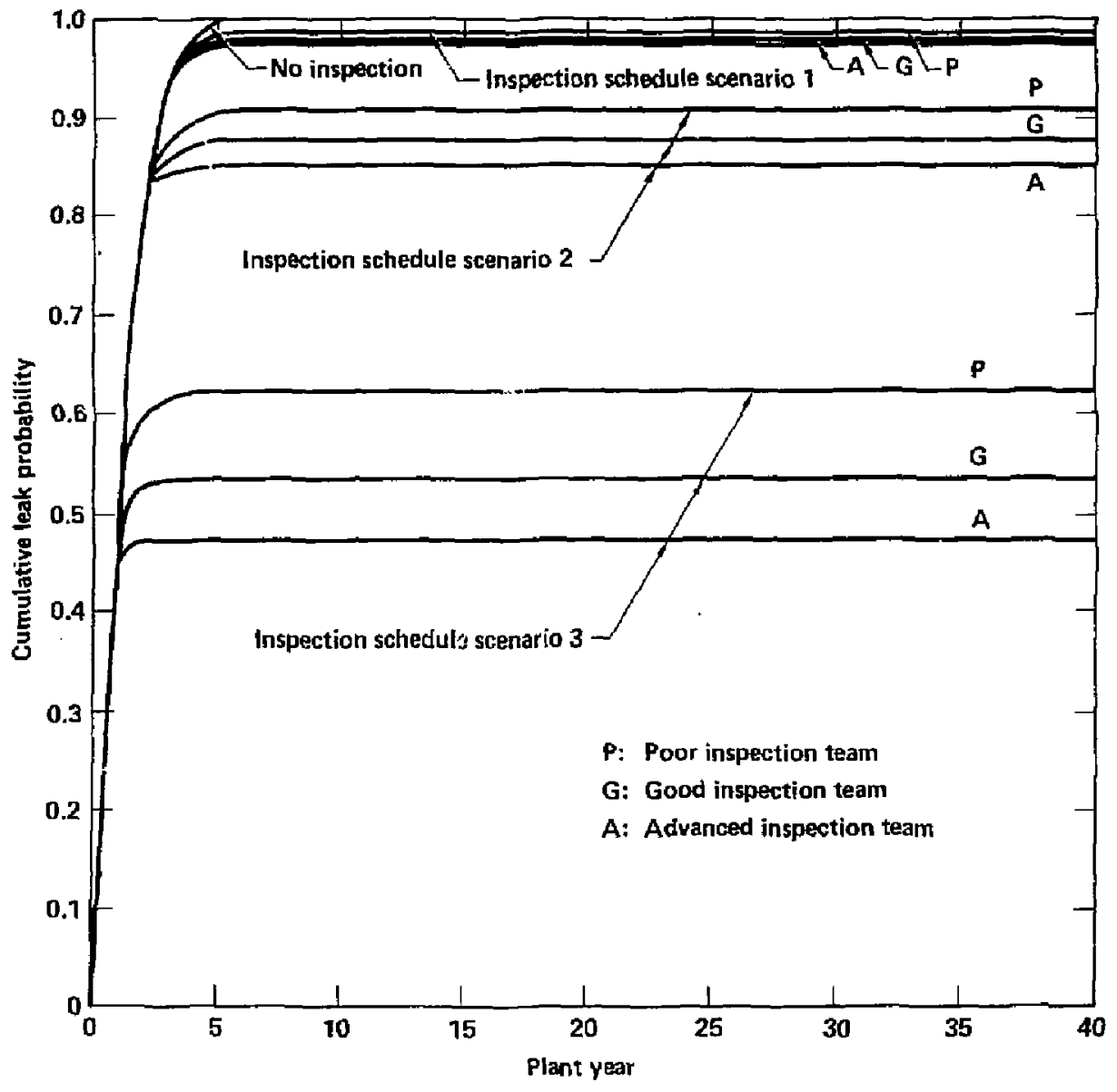

Figure 3a. Cumlative leak prciabilities for a PWR (plant A) feedwater steam generator nozzle with respect to three inspection teams and inspection schedules 1,2 and 3 over 40-year plant life. 


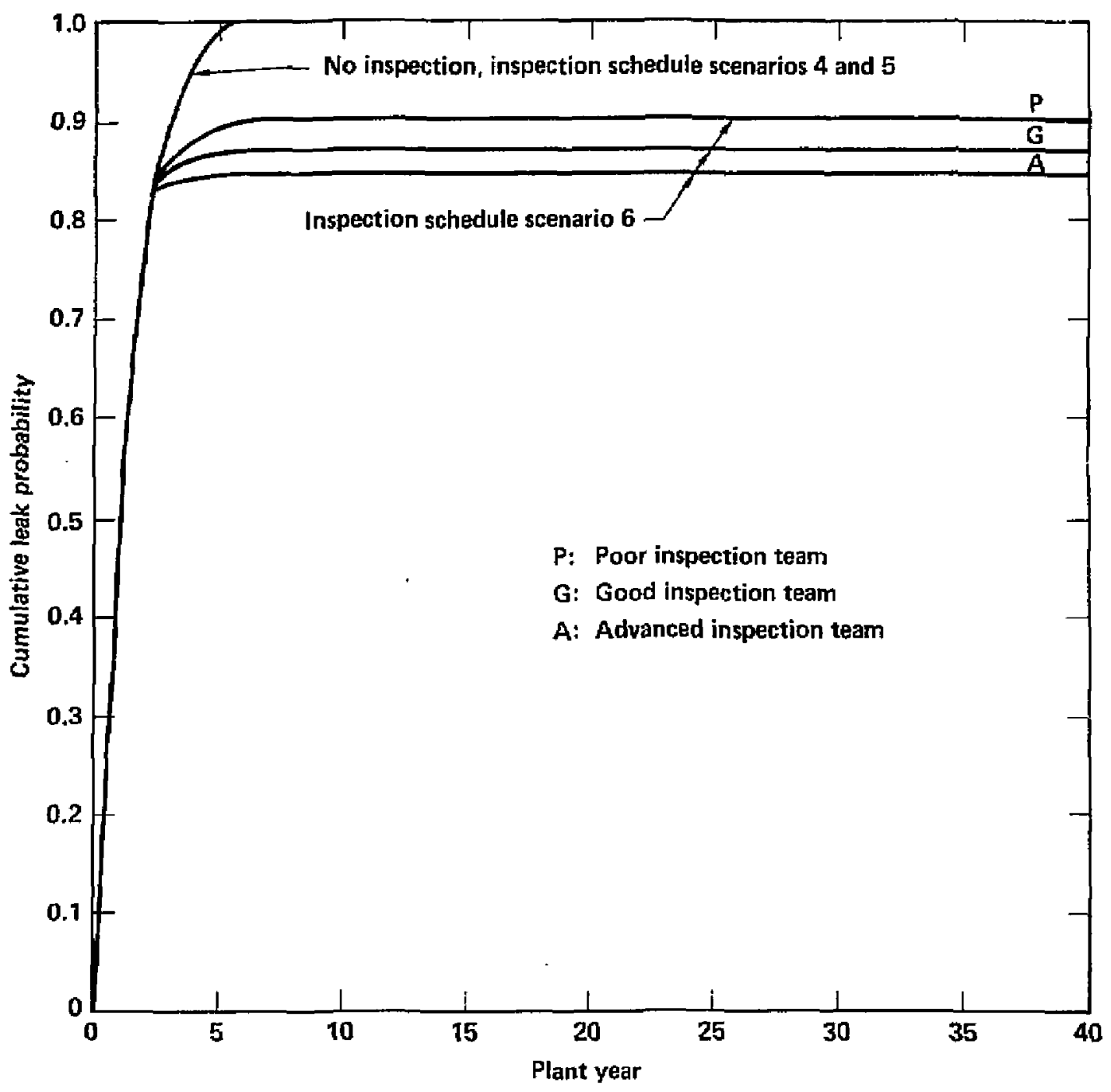

Figure 3b. Cumulative leak probabilities for a PWR (plant A) feedwater steam generator nozzle with respect to three inspection teams and inspection schedules 4, 5, and 6 over 40-year plant life. 


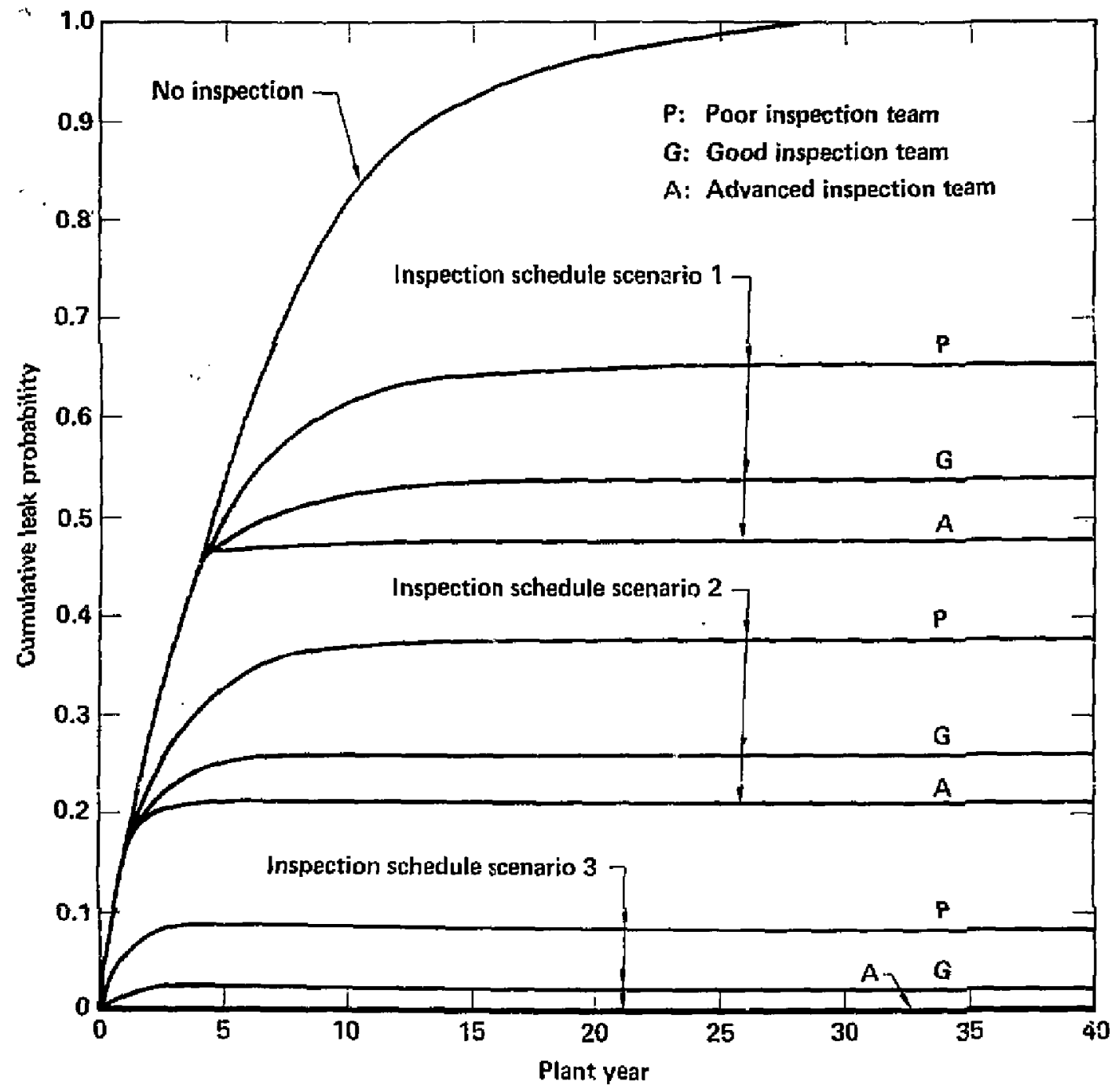

Figure 4a. Cumilative leak probabilities for a PWR (plant B) feedwater steam generator nozzle wi th respect to three inspection teams and inspection schedules 1,2 , and 3 over 40 -year plant life. 


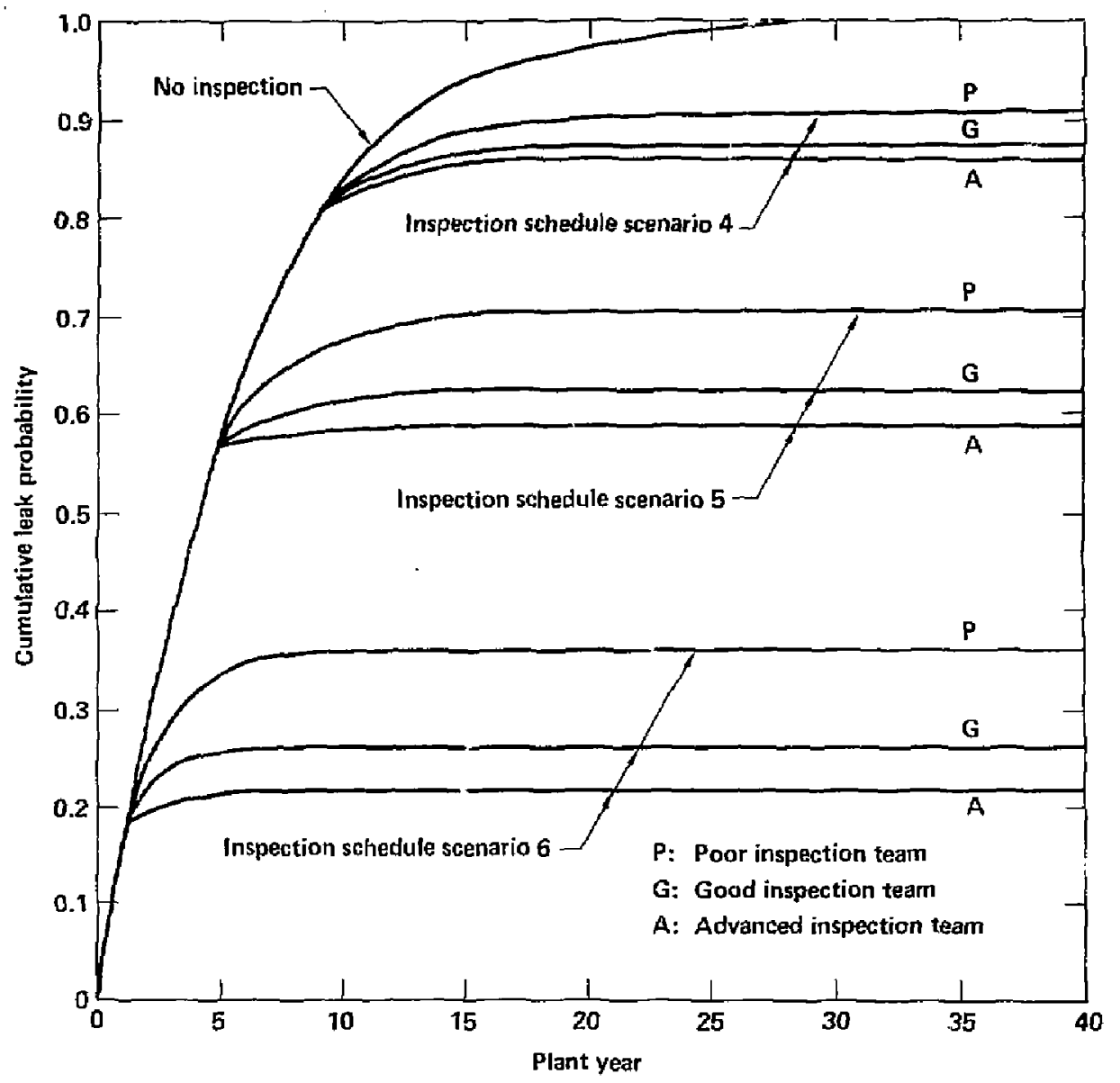

Figure 4h. Cumulative leak probabilities for a PHR (plant 8) feedwater steam generator nozzle with respect to three inspection teams and inspection schedules 4,5 , and 6 over 40 -year plant life. 
5. APFIOATION OF PIPING RELIABILIT\% MODEL TO BWR RECIRQULATION LINE CRACXING INCIDENT

\subsection{Background}

In June, 1978 a 3-gpm leak was discovered in one of the eight recirculation-inlet-nozzle safe ends at one BWR plant. ${ }^{13}$ The iecliculation-inletnozzle safe ends facilitate weloing of the stainless-steel inlet piping to the carbon-steel reactor- /essel nozzles. A thermal sleeve is welded into each safe end to direct coolant flow into the vessel. Figure 5 illustrates the configuration of the nozzle, safe end, piping, and thermal sleeve.

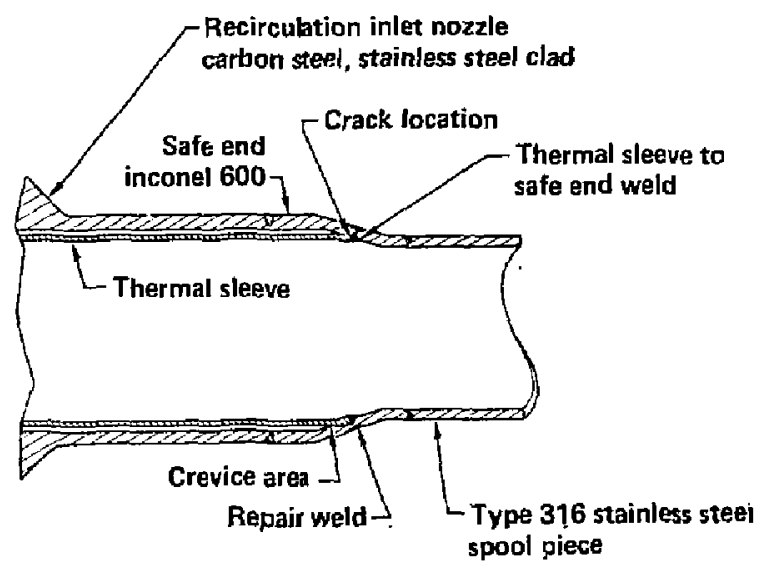

Figure 5. Recizculation-inlet-nozzle safe end configuration at a BWR plant.

Detailed fracture analyses 14 led to the conclusion that crack initiation and propagation resulted from a combination of high residual stresses and operating stresses fron the thermal-sleeve-attachment weld, the oxygen $\dot{A}_{1}$, the coolant, and a chemical environment, resulting from a crevice formed by the safe end/thermal-sleeve-attachment configuration. 


\subsection{Input Data for Piping Reliability Model}

1. Safe end geometry and material

outsicje diameter: 13.2 in.

thi.ckness: 1.15 in.

material: Inconel 600

2. Initial crack depth: 0.01 in.

3. Crack growth mode $1^{15}$

$$
\frac{d a}{d t}=c(k)^{m}
$$

where $a=$ crauk depth in inches,

$t=$ time in hours,

$C=$ lognormal distribution with median value $1.44 \times 10^{-8}$ and standard deviation $3.112 \times 10^{-8}$,

$\mathrm{m}=1.935$,

$K=\sqrt{\pi a}\left[A_{0} F_{1}+\frac{2 a}{\pi} A_{1} F_{2}+\frac{a^{2}}{2} A_{2} F_{3}+\frac{4}{3 \pi} a^{3} A_{3} F_{4}\right]$ in ksi $\sqrt{i \pi}$,

$F_{1}=1.1+0.9544(\mathrm{a} / \mathrm{h})+0.2920(\mathrm{a} / \mathrm{h})^{2}$

$F_{2}=1.0+0.2979(\mathrm{a} / \mathrm{h})+0.6042(\mathrm{a} / \mathrm{h})^{2}$,

$F_{3}=1.0+0.1292(\mathrm{a} / \mathrm{h})+1.083(\mathrm{a} / \mathrm{h})^{2}$,

$F_{4}=1.0+0.009165(\mathrm{a} / \mathrm{h})+0.5584(\mathrm{a} / \mathrm{h})^{2}$,

$A_{0}=81.84$,

$A_{1}=-413.26$,

$A_{2}=707.5$,

$A_{3}=-377.9$.

It should be noted that the median value of $C$ was determined from Eq. ( 9 ) by assuming initial crack depth 0.01 in. which resulted in pipe leak at specific time. Because of the lack of test data for growth rates of stress corrosion cracks in Incoriel, the standard deviation of $C$ was assigned to be identical to the one compiled from the test data for stainless steels under a similar corrosion environment. 16 
4. Loading conditions

The contributing stresses are those induced by pressure, dead welght, restraint of thermal expansion, and residual and peak stresses. The axial stress profile thraugh the pipe wall can be approximately expressed by the third-order polynomial

$$
\sigma(x / h)=A_{0}+A_{1}(x / h)+A_{2}(x / h)^{2}+A_{3}(x / h)^{3}
$$

where $x / h$ is the normalized radial distance measured from inside the pipe wall to an arbitrary point within the wall. $A_{0}, A_{1}, A_{2}$, and $A_{3}$ are the coefficients given in Eq. (9).

5. Crack detection probability

Since Inconel 600 piping was not part of the round rabin, the crack detection probability curves for stress corrosion cracks in welds within welds of wrought stainless steel piping were assumed to apply to Inconel 600 as well. Equation 4 in Section 2 gives three POD curves which are referred to as the poor, good, and advanced inspection reliability.

\section{Inservice inspection schedules}

Table 9 presents four scenarios for inservice inspection schedules. Inspections are assumed to be performed at the end of the year indicated in the table.

\section{$5.3 \quad$ R 3 sults and Discussion}

Cumulative leak probabilities for BWR recirculation line safe ends over 40-year plant life are expressed as functions of four inspection scenarios and three inspection teams. Figure 6a shows th:e leak probability over plant year for the poor inspection team with four inspection scenarios. It can be seen that; when compared with the case of no inspection, the reliability at the safe end is not improved significantly by inservice inspection even with an augmented inspection program such as scenario 1 . In other words, the team with the poor flaw detection capability is of no benefit in improving the reliability of this safe end regardless of the inspection schedule chosen. 
However, both good and advanced inspection teams provide an improvenent in reducing leak probabilities as showr in Figs. $6 b$ and $6 c$, respectively. A good inspection team can cut dowi the leak probabilities for the safe end from about unity to 0.89 (scenario 1 ), to 0.69 (scenario 2), to 0.32 (scenario 3), and to 0.11 (scenario 4) at the end of plant iife. With the help of an advanced team, the leak probahilities become 0.87 (scenario 1 ), 0.65 (scenario 2), 0.26 (scenario 3) and 0.06 (scenario 4) at the end of plant life.

A comparison of results shown in Figs. $6 b$ and 60 indicates that the improvement for the good inspection team is comparable to that for the advanced team. As for the PWR feedwater line example, the leak probabilities appraach unity early in the plant life. Evidently, in this situation the inspection interval is of primary importance once a mininial or requireo reliability level of nondestructive examination (NDE) is adhieved.

Table 9. Inspection scenarios for a BNR

recirculation line reactor vessel safe-end nozzle.

\begin{tabular}{|c|c|c|}
\hline Scenario & Description & Inspection Sothedule (end of year) \\
\hline 1 & ASME Program B* & $10,20,30,40$ \\
\hline 2 & $\begin{array}{l}1 / 2 \text { inspection intervals } \\
\text { of scenario } 1\end{array}$ & $5,10,15, \ldots, 35,40$ \\
\hline 3 & $\begin{array}{l}\text { 1/5 inspection intervals } \\
\text { of scenario } 1\end{array}$ & $2,4,6, \ldots, 38,40$ \\
\hline 4 & $\begin{array}{l}\text { 1/lo inspection intervals } \\
\text { of scenario } 1\end{array}$ & $1,2,3, \ldots, 39,40$ \\
\hline
\end{tabular}

* Refeis to ASME Boiler and Pressure Vessel Code, Section XI, Inservice Inspection Program 


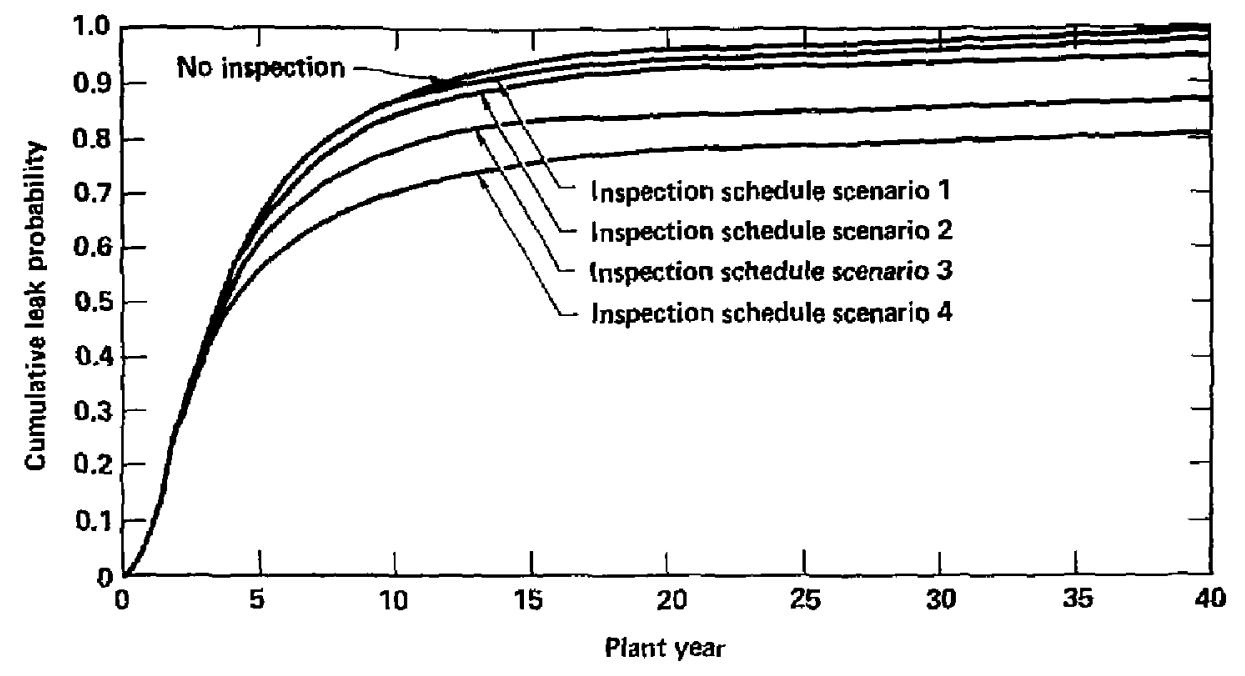

Figure 6a. Cumulative leak probabilities for a BWR recirculation reactor vessel nozzle safe end with respect to a poor inspection team and four inspection schedules over 40-year plant life.

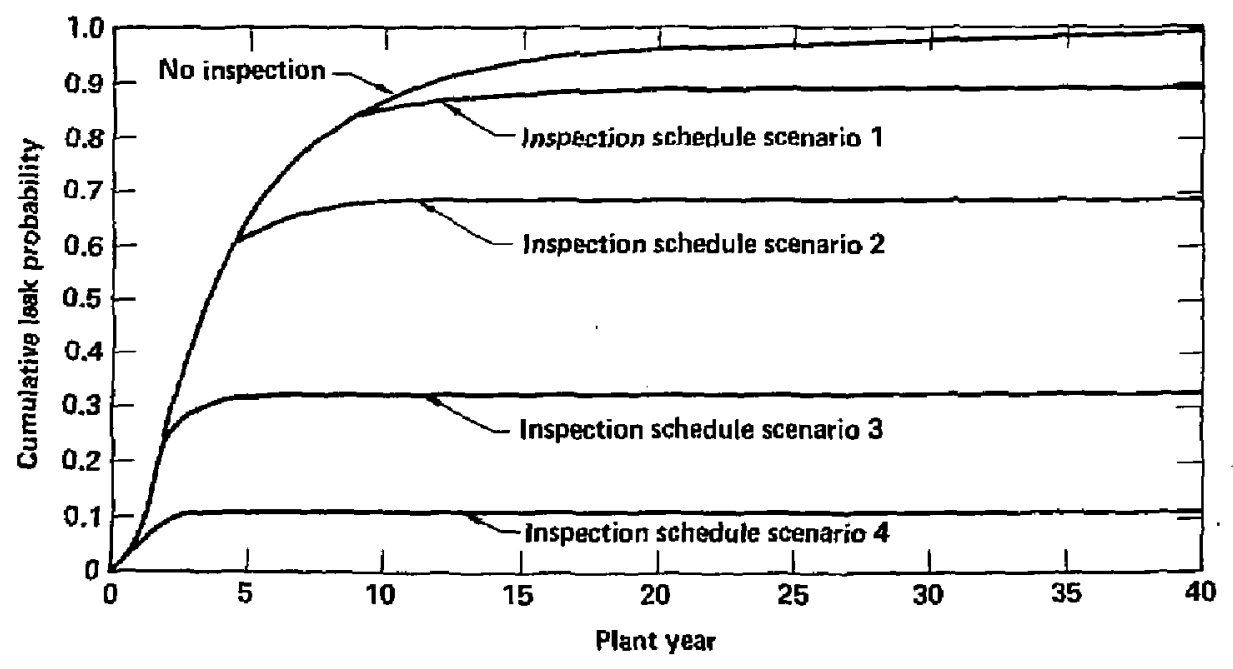

Flgure 6b. Cumulative leak probabilities for a BNR recirculation reactor vessel nozzle safe end with respect to a good inspection team and four inspection schedules over 40-year plant life. 


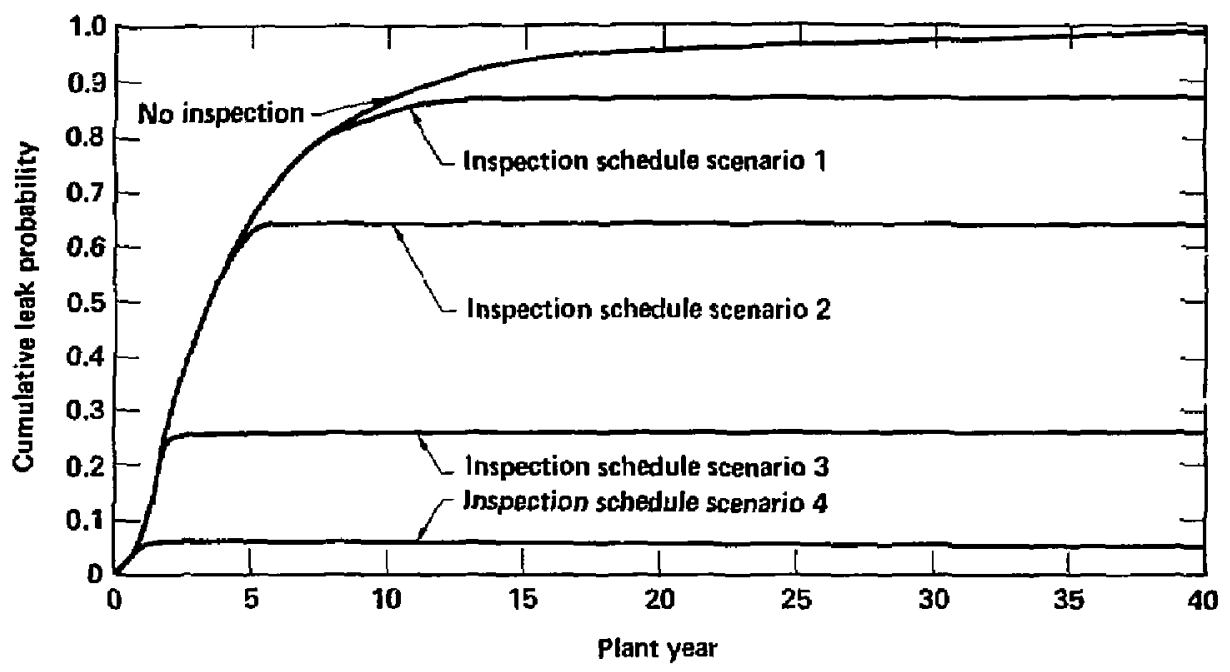

Figure 6c. Cumulative leak probabilities for a BWR recirculation reactor vessel nozzle safe end with respect to an advanced inspection team and four inspection schedules over 40-year plant iife. 
The impact of inservice inspection on the reliablity of nuclear piping has been evaluated for two service failure incidents using the probabilistic fracture mechanics approach. Based on the analysis results for the selected scenarios, we coserved the following points:

(1) An effective inservice inspection requires a suitable contination of flaw detection capability and inspection schedule.

(2) The first service inspection is the most important one, if flaws have the potential to grow to critical size in the early stage of plant operation.

(3) An augmented inspection schedule is required for these particular piping lines with fast-growth flaws to ensure that the inspection is done before the flaws reach critical sizes.

(4) For the PNL round $\mathrm{r}$ obin study, the improvement in leak probability reduction from the "good" team to the "advanced" team is less than that from the "poor" team to the "good" team.

Although the findings in the study may not be applicable to all piping systems, we believe that the probabilistic approach presented is suitable for assessing the impact of inservice inspection of some piping systems. The focus of this study was on lines with high failure probabilities early in the plant life. For these lines it appears that the effectiveness of inservice inspection is dominated by the inspection period rather than the flaw detection capability.

In viewing the results of this study (Figs. 3, 4, and 6), improvements in detection probability from poor-to-advanced teams are clearly reflected by the decrease in slope of the leak probability curves at the time of the first inspection. There is a clear difference among the performance levels for the three detection capabilities (poor, good, and advanced). In systems with low leak probabilities early in life and with an increasing fallure rate, the differences in slope have a large bearing on the system reliability. Results of 
a study ${ }^{17}$, which applied the flaw detection capability data generated by the FNL round robin experiments to stress corrosion cracking incidents in stainless piping verified this conclusion.

Arother assumption made in the plping reliabjlity model also impacts the effectiveness of inservice inspections. The.model assumes that piping with leaks or detected cracks is replaced by "perfect" material. Thus over the 40-year plant life, failures will not occur at the previous critical piping locations. Cbviously, this assumption tends to minimize the differences on leak probability resulting from different flaw detection capabilities as well as different inspection schedules. 
REF שRENCES

1. S. R. Doctor, F. L. Becker, and G. B. Selby, "Effectiveness and Rel lability of U.S. In-Service Inspection Techniques, "Periodic Inspection of Pressurized Camponents, I. Mech. E. Conf. Publlations 1982-9, the Institution of Mechanical Engineers, pp. 291-294, 1982.

2. D. 0. Harris, et al., "Fracture Mechanics Models Developed for Piping Relfability Assessinent in Light Water Feactors," Lawrence Livermore National Laboratory, UCID-53040 NLREG/CE-2301, April 1982.

3. F. 1.. Becker, et aI., "Integration of NDE Reliability and Fracture Mechanics," Pacific Nor thwest Laboratory, PNL-..469 NUREG/CR-1696, Vol. 1, March 1981 .

4. A. M. Mood, F. A. Grewill and D. C. Boes, Introduction to the Theory of Statistics, Third Edition, McGraw Hi]', New York, pp. 107-108, 1974.

5. Letter from F. A. Simonen to H. H. Woo, private communication dated June $17,1982$.

6. Letter from F. A. Simonen to H. H. Wod, jrivate communication dated February $24,1983$.

7. Pipe Crack Study Group, "Investigation and Evaluation of Cracking Incidents in Piping in Pressurized water Reactors," U.S. Nuclear Regulatory Commission, Washington, D.C., NUREG-0691, September 1980.

8. Westinglouse Electric Corporation, "Investigation of Feecwater Line Cracking in Pressurized Water Reactor Plants, "Pittsburgh, Pennsylvania, WCAP-9693, June 1980.

9. ASME Boiler and Pressure Vessel Code, Section XI, Rules for Inservice Inspection of Nuclear Power Plant Components, American Society of Mechanical Engineers, New York, pp. 274-277, 1983. 
10. Letter from F. A. Simonen to H. H. Won, private communication dated october 5, 1982.

11. W. H. Bamford, A. Thurnar: and M. Mahlab, MFatlgue Crack Growth in Pressurized Water Reactor Feedwater Lines," Joint Conference of the Pressure Vessels and Piping Materials, Nuclear Engineer ing and Solar Divisions, Denver, Colorach, June 21-25, 1960.

12. H. H. Woo and C. K. Chou, "Plping Reliability Model Validation and Potential Use for Licensing Regulation Development," Lawrence Livermore National Laboratory, UCRL-53050 NUREG/CR-2801, January 1983.

13. Pipe Crack Study Group, "Investigation and Evaluation of Stress-Corrosion Cracking in Piping of Light water Reactor Plants," Nuclear Regulatory Commission, Washington, D.C., NLREG-0531, February 1979.

14. H. C. Burghard, Jr., Metallurgical Investigation of Cracking in a Reactor Vessel Nozzle Safe-End", Southwest Research Institute, San Antonio, Texas, SwRI Project 02-5389-001, Dctober 1978.

15. L. Boyce and $H . H$. Woo, "Piping Reliability Analysis for Recirculation Safe Ends of a Boiling Water Reactor," the 7th International Conference an Structural Mechanics in Reactor Technology, Paper Ml/5, Chicago, Illinois, August 22-26, 1983.

16. Letter from F. A. Simonen to H. H. Woo, private communication dated March 9, 1983.

17. S. R. Doctor, et. al., "Integration of Nondestructive Examination Reliability and Fracture Mechanics," Proceedings of the Eleventh Water Reactor Safety Research Information Meeting, Gaithersburg, Maryland, Dctober 24-28, 1983. 